UDC 929 Claudius C.

Snežana Vukadinović

Univerzitet u Novom Sadu

Filozofski fakultet

Odsek za istoriju

snezana_vukadinovic@yahoo.com
Originalan naučni rad

primljeno: 1. jul 2012

prihvaćeno: 1. oktobar 2012

\title{
„NAHRANILA ME ALEKSANDRIJA, K'O IZBEGLICU ZAKOPA ME RIM““”
}

Sažetak: Autor rada daje niz istorijskih izvora koji direktno i indirektno ukazuju na životni put Klaudija Klaudijana (Claudius Claudianus, 370.-408. godine), najvećeg rimskog pesnika poznog Rimskog carstva. Uprkos svom latinskom imenu, Klaudijan je došao sa grčkog Istoka, iz grčke Aleksandrije u Egiptu. Svoje obrazovanje duguje najpoštovanijim i najučenijim aleksandrijskim profesorima toga doba. Politički i religiozni raskol rušio je Rimsko carstvu iznutra. Dekadencija se osećala na svakom koraku, ali kao nekim čudom u Egiptu je, u to vreme, cvetalo pesništvo.

Ključne reči: Claudius Claudianus, Klaudije Klaudijan, Egipat, egipatski pesnici, Aleksandrija, Rim.

Razarajuća istorijska dešavanja ${ }^{1}$, već podeljenog Rimskog Carstva, vreme su života i rada Klaudija Klaudijana, jednog od najtalentovanijih antičkih rimskih pesnika ${ }^{2}$. U istoriji književnosti mnogi naučnici Klaudija Klaudijana smatraju za poslednjeg velikog pesnika Rima. To mračno i opasno doba na književnu scenu kao nekim čudom iznedrilo je talentovanog pesnika Klaudija Klaudijana. Malo toga se zna o Klaudijanovom životu. Jedini savremenici koji su ga pominjali su Sveti Augustin i Orosije. Njihovi stavovi bili su vrlo jasni u svojoj oceni pesnika. Augustin kad je prikazivao Teodosijevu pobedu kod Frigida na jednom mestu dodaje: unde et poeta Claudianus, quamvis a Christi nomine alienus, in eius laudibus dixit... ${ }^{3}$ Orosije $^{4}$ je još oštriji, kaže za njega da je paganus

\footnotetext{
* Rad predstavlja fazni rezultat istraživanja za dva projekta: Vojvođanski prostor u kontekstu evropske istorije (br. 177002) finansiran od strane Ministarstva prosvete i nauke Vlade Republike Srbije i Srednjovekovna naselja na tlu Vojvodine. Istorijski procesi $i$ događaji, br. Rešenja 114-451-2216/2011, koji finansira Pokrajinski sekretarijat za nauku Vlade Autonomne pokrajine Vojvodine.

${ }^{1}$ Amm. Marc., XXXI, 13, 19; H.Leppin 2003, 205-220.

${ }^{2}$ Među poslednjim rimskim pesnicima treba istaći i Dekima Magna Auzonija (330-393) i Klaudija Rutilija Namacijana (početak 5. veka)

${ }^{3}$ Aug. De civ. Dei 5.26
} 
pervicacissimus. Dakle, oni nam govore tek toliko da je bio pesnik i pagan. Najduži tekst koji govori o njemu je natpis na bazi za njegovu statuu podignutu na Trajanovom forumu u Rimu. Porfirna baza sa natpisom (CIL VI, 1710 =Dessau 2949) danas se čuva u Napulju ${ }^{5}$.

Detaljnu istoriju o periodu koji obuhvata Klaudijanovu poetsku aktivnost napisao je retoričar Eunapije ${ }^{6}$ iz Sarda, njega je nastavio Olimpiodor ${ }^{7}$, pesnik i diplomata iz egipatskog grada Tebe. Pošto je Klaudijan stekao značajnu slavu još za života, i kao pesnika i kao neko ko slavi svemoćnog vojskovođu Stilihona, moguće je da bi nam bar jedno od ovih dela moglo reći nešto o njemu. Ali, nažalost, oba su nestala, i ono što se može naći danas, tek je nepotpun i nevažan epitom preveden kao c. 501 od bivšeg pravnika Zosima ${ }^{8}$ koji čak ni ne pominje Klaudijana. Zaista, daleko najvažniji izvor iz tog perioda uopšte, je sam Klaudijan. Njegovi panegirici, invektive, svadbene pesme, isrorijski epovi, mitološki epovi, epigrami i zbirka manjih pesama razuđenog stila na latinskom i nešto malo na grčkom jeziku su neprocenjive za istoročara koji bi želeo da rekonstruiše burne godine koje su usledile posle smrti Teodosija Velikog. Ali, ne toliko zbog činjenica, koje su malobrojnije nego što se ponekad misli, već zbog uvida u suštinu politike i intrige tog doba, koji je dublji nego što se generalno pretpostavlja. Nažalost, u najboljoj epskoj tradiciji, oni govore veoma malo o samom autoru. Nešto više se može sakupiti iz njegovih epigrama, iako malo toga o ličnom životu.

Datum njegovog rođenja je nepoznat. Pretpostavlja se da se morao roditi negde između 370. i 375. godine, ali izgleda da je još bio mlad kada je došao u Rim, 394. godine. U pesmi napisanoj 397. godine još uvek je mogao da krivi ,grešku prosuđivanja, za svoje lubrica aetas ${ }^{9}$. On sebe naziva sodalis ${ }^{10}$ drugom i vršnjakom Olibrija, mladog konzula iz 395. godine, koji je rođen 376. godine. Njihovo prijateljstvo pesnik poredi sa onim između Pilada i Oresta. Ovo ukazuje na to da Klaudijan ni u kom slučaju nije bio mnogo stariji od Olibrija, koji je bio u ranim dvadesetim godinama u to vreme. Tako da 370. godina verovatno ne bi bila puno udaljena od godine njegovog rođenja ${ }^{11}$.

\footnotetext{
${ }^{4}$ Oros. Adv. pg. 7.35.21.

${ }^{5}$ Camerun 1970, 15; Milićević 1997, 24

${ }^{6}$ Eunapije (Eunapios), živeo je otprilike od 345. do 420. godine, iz Sarda. Pisao je biografije uglavnom neoplatoničara (Biol $\sigma 0 \varphi \imath \sigma \tau \hat{\omega} v)$. U svom istorijskom delu, sačuvanom samo u izvodima, nastavlja Deksipovu hroniku i obrađuje vreme od 270. do 404. godine. Delo je pisano u antihrišćanskom tonu.

${ }^{7}$ Olimpiodor (Olympiodoros), živeo je skraja 4. i do sredine 5. veka. Poreklom je iz egipatskog grada Tebe. Stekao je dobro obrazovanje. Upoznao se sa neoplatonskom filozofijom. Pored grčkog i koptskog jezika savladao je latinski jezik kako bi mogao da napreduje u karijeri. Bio je u mnogim diplomatskim misijama kao carski službenik Teodosija II. Napisao je Istoriju Rima, tačnije period od 407. do 425. Delo nije sačuvano, ali postoje neki fragmeni za koje Fotije kaže da sadrže dragocenu građu. Prema Fotiju Olimpiodor sebe naziva pesnikom, ali nije sačuvan nijedan stih pod njegovim imenom. Alan Kamerun istražujući egipatske književnike 4.i 5. veka svrstava ga u grupu „lutajućih pesnika“. Vidi: Photius, Cod., 80 i 314 uvod.; uporedi Historia XIV, 1965, 476, f.n.37; E.A. Thompson, CQ XXXVIII, 1944, 43 f.

${ }^{8}$ Zosim (Zosimos), živeo je u drugoj polovini 5. veka. Rodom, verovatno iz Gaze. Bio je visok državni službenik pod carem Teodosijem II. Napisao je rimsku istoriju na grčkom jeziku, u kojoj daje ukratko pregled događaja od cara Augusta do Dioklecijana, a od tog doba pregled postaje opširniji do 410. godine

${ }^{9}$ Carm.min. XXII. 6

${ }^{10}$ Carm.min. 40, 18-19.

${ }^{11}$ Birt 1892, VI; Platnauer 1922, XII; Camerun 1970, 1.
} 
Uprkos svom latinskim imenu, njegovo ime ne možemo tumačiti kao što su se tumačila imena u doba republike, tj. da oni koji su u slobodi rođeni imaju praenomen, nomen i cognomen ${ }^{12}$. Ime je latinizovano ali ono odražava zapravo grčku tradiciju davanja imena, dakle, Claudius Claudianus je Klaudijan Klaudijanov sin. Znamo da nije bio rođeni Rimljanin, već da je rođen u Egiptu, što je pesnik jasno istakao u dva epigrama. Jedan je napisao izvesnom Genadiju, koji je bio, bar kako Klaudijan tvrdi,

$$
\begin{aligned}
& \text { Graiorum populis et nostro cognite Nilo... }{ }^{13} \\
& \text { iz Grčkog naroda i našeg poznatog Nila... }{ }^{14}
\end{aligned}
$$

U drugom se obraća jednom visokom dvorskom službeniku Hadrijanu, kao svom sunarodniku iz Egipta:

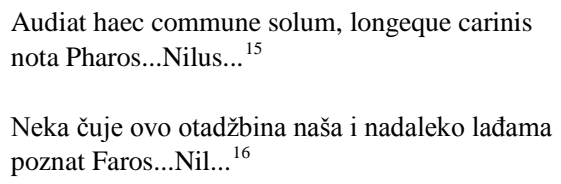

Nešto ranije u istoj pesmi on ističe Aleksandra Velikog kao conditor hic patriae. Ovo svakako znači Aleksandrija. A to da je Klaudijan zaista bio iz Aleksandrije, danas se gotovo svi istraživači slažu. To potvrđuje i Suda u zapisu preuzetom iz biografskog rečnika iz 6. veka koji je objavio Hesihije iz Mileta ${ }^{17}$.

Postoje još dva teksta koji su naučnici ponekad preferirali više od ovog jasnog svedočenja. Sidonije Apolinar aluzijom ukazuje na Klaudijana kao na Pelusiaco satus Canopo $^{18}$. Ali svako ko je upoznat sa Sidonijevim stilom, kaže Kameron, odmah će shvatiti da je ovo samo njegov poseban način da ne kaže samo „Egipat,, - što je preuzeo iz Lukanovog stiha Nilusne ... et Pelusiaci tam mollis turba Canopi. ${ }^{19}$ A, Jovan Lidijac ${ }^{20}$ na

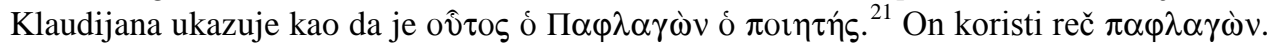
Teodor Birt je to shvatio, u smislu ,,galamdžija,, ili „,brbljivac,., Ta reč se redovno sreće u Aristofanovim grubim i neučtivim primedbama na račun Kleona. Od najranijih vremena

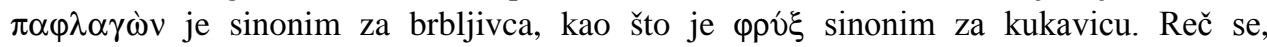
najverovatnije, koristila u tom kontekstu i u Jovanovom vremenu. Ovo je dokazano preko

\footnotetext{
${ }^{12}$ Uporedi Milićević 1997, 7.

${ }^{13}$ Carm.min. XIX, 3.

${ }^{14}$ prevela Snežana Vukadinović

${ }^{15}$ Carm.min.XXII, $56 \mathrm{f}$.

${ }^{16}$ Prevela Snežana Vukadinović

${ }^{17}$ Cameron 1970, 23; Schanc 1920, 3; Rostagni II 1955, 562.

${ }^{18}$ Carm. IX, 274.

${ }^{19}$ Phars, VIII, 542-3.

${ }^{20}$ Jovan Lidos, na Zapadu je po očevom imenu nazvan i Laurentije. Živeo je u prvoj polovini 6. veka. Bio je učitelj retorike u Carigradu. Autor dela $O$ mesecima, O predznacima, $O$ rimskim državnim praznicima Vidi i uporedi: J. Turcevič, Byz. Zeit. XXXIX, 1934, I f ; Sledio je F. Bücheler, Rhein. Mus. XXXIX, 1882, 282 f.

${ }^{21}$ De Mag. I, 47.
} 
potpuno paralelnog primera kod Prokopija, ${ }^{22}$ kako ga je protumačio Hauri ${ }^{23}$, ali potpuno nezavisno od Birtove rasprave i očigledno bez znanja bilo za Jovanovu paralelu, ili za onu kod Palade ${ }^{24}$. Dovoljno je zaključiti da nema razloga za sumnju u Hesihijevo svedočenje, pošto je potvrđeno ličnom Klaudijanovom izjavom, da je rođen u Aleksandriji.

Treba istaći i Rouzov stav. Naime, ovaj istraživač tvrdi da Klaudijan piše u Egiptu (i stoga, pošto je on bio pismen čovek, u Aleksandriji). ${ }^{25}$ Ali, iako je možda bilo tačno u Kalimahovo vreme da su se pismeni ljudi iz Egipta, obavezno nalazili u Aleksandriji, to sigurno nije bio slučaj u Klaudijanovo vreme. U 4. veku, Egipat je postao najveći izvor pesnika, u celom carstvu. Skoro je nemoguće navesti nekog istaknutog grčkog pesnika iz 4. ili 5. veku koji nije bio Egipćanin, ili koji nije bio u nekoj meri obrazovan u Egiptu. Kao što je Eunapije rekao Egipćani su ludi za poezijom ${ }^{26}$, ali ipak, od svog tog mnoštva egipatskih pesnika, samo su Klaudijan i Paladije ${ }^{27}$, dokazano, iz Aleksandrije. Skoro svi ostali pesnici bili su iz Tebe. Najplodnije tle za pesnike tog doba, bez sumnje bio je Panopolis ${ }^{28}$, koji je, kako je Herodot primetio, još u njegovo doba bio sposoban da upije grčku kulturu. Taj grad se proslavio Nonom, Trifiodorom, Kirom, Pamprepijem i Horapolonom, kao svojim učenicima. ${ }^{29}$ Ali mnogi egipatski pesnici 4., 5., i ranog 6. veka, bili su građani i drugih gradova u egipatskom priobalju, tačnije iz Gornjeg Egipta. Skoro po hronološkom redu tu su Soterih ${ }^{30}$ iz Oaze, Heladije ${ }^{31}$ i Kir $^{32}$ iz Antinopolja, Andronik ${ }^{33}$ iz Hermopolisa, Eudemon ${ }^{34}$ iz Pelusija i Heraklid ${ }^{35}$ iz Memfisa, Olimpijodor $^{36}$ iz Tebe, Kolut ${ }^{37}$ iz Likopolisa, Hristodor ${ }^{38}$ iz Kopta, drugi Hristodor ${ }^{39}$, ali iz Tebe, i na kraju, ali ne i najmanje važan, Dioskor ${ }^{40}$ iz Afroditopolisa. Kleobul, ${ }^{41}$

\footnotetext{
${ }^{22}$ Anecd. XVI, 7.

${ }^{23}$ Byz. Zeit, IX, 1900, 647.

${ }^{24}$ Cameron 1970, 253.

${ }^{25}$ Rose 1954, 529, f.n. 193.

${ }^{26} \dot{\varepsilon} \pi \hat{\imath} \pi 0 \imath \eta \tau \imath \kappa \hat{\eta} \sigma \varphi o ́ \delta \rho \alpha \mu \alpha i ́ v o v \tau \alpha \imath$, Vit.Soph., X, 7, 12, 493

${ }^{27}$ Paladije (Palladios), živeo u 4. veku, iz Galateje, grčki hagiograf. Živeo je u Egiptu kao kaluđer, pa je posle postao episkop u Helenopolisu u Bitiniji, kasnije u Asponi u Galatiji. U tzv. Historia Lausiaca (nazvanoj po Lausu, carskom dvorskom rizničaru, kome je delo posvećeno), opisuje monašaki život u Egiptu i Palestini. Njegova biografija Jovana Zlatoustog, koji mu je bio prijatelj, sačuvana je. Napisna je u obliku dijaloga i služi u apologetske svrhe.

${ }^{28}$ Panopolis je grčka kolonija u Egiptu. Herodot ga prvi put naziva Hemis. Grad je poznat po čuvenim kamenolomima, proizvodnji lana, a kasnije i pamuka. Danas je to grad Ekmim ili Akmim.

${ }^{29}$ Uporedi: Historia, XIV, 1965, 472.

${ }^{30}$ Glavni izvor je Suda pod traženim imenom. Vidi: Cameron 1970, 4, f.n.5.

${ }^{31}$ Photius, Cod., 279.

${ }^{32}$ Photius, Cod., 279. do kraja; (tačna godina nije definisana, ali u pitanju je 4. vek).

${ }^{33}$ Isto. Uporedi Historia XIV 1965, 487-489.

${ }^{34}$ Isto.

${ }^{35}$ Libanius, Epp. 228, 229, 291, 292, 839.

${ }^{36}$ Am.Marc., XVI, 5, 7.

${ }^{37}$ Kolut (Kolluthos), kraj 4. i početk 5. veka, iz Likopolisa. Njegov kratki grčki ep sadrži svega 394 stiha Otmica Jelene napisan je pod Nonovim uticajem. Vidi: Leksikon Suda pod traženim imenom ; uporedi Oxford Classical Dictionary II, pod traženim imenom.

${ }^{38}$ Suda pod traženim imenom; Anth. Pal., II; OCD II, pod traženim imenom.

${ }^{39}$ Suda pod traženim imenom.

${ }^{40}$ Heitsch XLII, 5. 62. Za druge fragmente i bibliografiju vidi: Historia XIV 1965 477-478.
} 
Harpokrat, ${ }^{42}$ Serenus, ${ }^{43}$ i neimenovani pesnik ${ }^{44}$ koga je pomenuo Temistija ${ }^{45} 377$. godine opisani su kao „Egipćani, bez suvišnih detalja, a Musajo ${ }^{46}$, autor dela Hera i Leandar, bi se možda mogao dodati toj grupi. ${ }^{47}$ Pored toga, postoji i mnogo anonimnih fragmenata iz radova manje poznatih egipatskih pesnika tog vremena, neki su u vidu kopija koje su ti pesnici sami pisali, uz njihove, rukom pisane ispravke. Na primer, deo pesme $o$ Dioklecijanovom i Galerijevom Persijskom ratu od 297. do 298. godine, što verovatno nije, kao što se mislilo, Soterihovo delo ${ }^{48}$. Zatim jedan odlomak drugog dela $o$ Heraklijevom Egipatskom pohodu ${ }^{49}$, koji je bio general u vreme cara Zenona ${ }^{50}$, i još jedan istorijski ep o pohodu, inače, nepoznatog generala Germana, protiv Blemija. ${ }^{51}$ Jedno delo od posebnog značaja je fragment kosmološke poeme o osnivanju Hermopolisa. ${ }^{52}$ Takvo otkriće je i fragment iz Antinopolja, objavljen 1967. godine, hvalospev o guverneru po imenu Arhel. ${ }^{53}$

Nema sumnje da su mnogi od ovih pesnika bar neko vreme proveli učeći u učionicama i bibliotekama Aleksandrije, ali očigledno je da Aleksandrija više nije bila jedini grad u Egiptu koji ima škole ili literarnu tradiciju koja bi mogla da posluži pesnicima. Nije više bilo razloga da Egipćani sebe smatraju manje vrednim, ako nisu

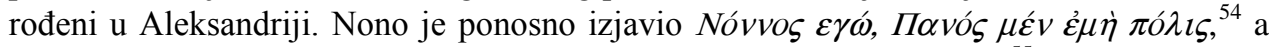
Olimpijador se hvalio time da je i sam Homer rođen u egipatskoj Tebi. ${ }^{55}$ Stoga Klaudijan nije morao da tvrdi da mu je Aleksandrija rodni grad, osim ako je to jednostavno bilo istina.

Mojsije Hadas ${ }^{56}$ tvrdi da, pošto Klaudijan ne navodi svoje Aleksandrijsko poreklo u svojim najvažnijim pesmama na latinskom, mora da je sebe držao građaninom drugog reda dok je živeo u Rimu i Milanu. Ovo mišljenje nije utemeljeno, jer je Aleksandrija bila treći grad po veličini u carstvu. Na ovo ukazuje epitaf jednog ranijeg Aleksandrijca u Rimu:

\footnotetext{
${ }^{41}$ Libanius, Ep., 361.2.

${ }^{42}$ Libanius, Ep., 368.

${ }^{43}$ Photius, Cod., 279 do kraja.

${ }^{44}$ Or. XXIX, 347. Moguće je da je taj nepoznati pesnik Horapolon, uporedi Historia XIV, 1965, 488.

${ }^{45}$ Temistije (Themistios), otprilike 317-388, iz Paflagonije. Bio je najuticajniji grčki sofista 4. veka. Živeo je u Carigradu, bio je senator i vaspitač prestolonaslednika Arkadija i upravnik jedne retorske škole.

${ }^{46}$ Musajo (Musaios), živeo je kraj 5. do sredine 6. veka. Bio je grčki epski pesnik iz tzv. Nonove škole. Jezikom i građom stihova podražavao je Nona.

${ }^{47}$ Cameron 1970, 24-24, f.n.2, 3.

${ }^{48}$ Keydell, Hermes 61, 1936, 465-7.

${ }^{49}$ Isto.

${ }^{50}$ Zenon je bio vizantijski car. Vladao je od 474. do 491. godine.

${ }^{51}$ Cameron 1970, 26, f.n. 3.

52 Isto. Uporedi Keydell 1941, 13, 242.

${ }^{53}$ Cameron 1970, 5, f.n.12.

${ }^{54}$ Anth. Pal., IX, 198.; Wifstrand 1933, 166-168.

${ }^{55}$ Hist., frag., 33 (FHG IV, 65a) Grčki pesnici u vreme Carstva su generalno naglašavali mesto svoga porekla. Na primer Opijan (2. vek) napominje svoj rodni kraj provinciju Siriju i Kilikiju. Vidi: Cyn. II 125 f.; Hal. III, 7 f.; Takođe i Kvint (4. vek) koji je sebe nazvao Kvint Smirnjanin, autor epa Događaji posle Homera, našao je način da nas obavesti o svom rodnom kraju. Vidi: XII, $308 \mathrm{f}$.

${ }^{56}$ Hadas 1952, 389; uporedi Levy 1958, 91.
} 


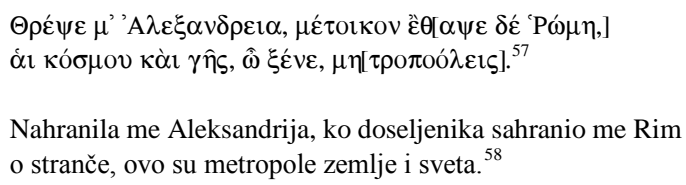

Svakako, nije postojao razlog da Klaudijan izloži lične detalje u formalnim epskim pesmama i hvalospevima. Ali u epigramima koji su na početku navedeni on to prilično otvoreno priznaje. Niko ko bi želeo da svoje egipatsko poreklo drži u tajnosti ne bi pisao podužu pesmu o izvorima Nila ${ }^{59}$ ili epigram o krokodilu. ${ }^{60}$ Takođe, ono što je Klaudijan ismevao kod Eutropija kao Aegyptia somnia Jovana pustinjaka, nije bio negativan stav prema već sinkretičkim tradicijama mediteranskih kultura, već više kritika upućena samom Eutropiju koji je hteo da se pokaže da je svoje izvore sakupljao iz prve ruke. I možda ne bi bilo previše maštovito pronaći ovde tragove tradicionalnog neprijateljstva između Aleksandrinaca i rođenih Egipćana - Kopta ${ }^{61}$

Kao čovek iz Aleksandrije, Klaudijanov maternji jezik je prirodno bio grčki, a iz epigrama koji je napisao verovatno 395. godine, Aniciju Probinu, drugom od konzula za tu godinu, može se zaključiti da je njegovo književno stvaralaštvo do tada bilo isključivo na grčkom:

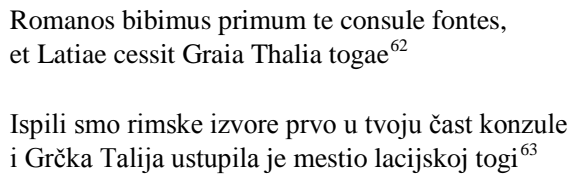

Jedna od tih pesmama je bila Gigantomahija, čija su dva fragmenta sačuvana. Prvi, uvod u pesmu, jasno pokazuje da je pesma recitovana u Aleksandriji. O ovome će se govoriti kasnije. Sedam epigrama sačuvano je u Grčkoj Antologiji i pripisuju se Klaudijanu. Ipak, još uvek se ne zna za dva ili tri od njih da li su zaista Klaudijanovo delo jer se pretpostavlja da su pisani od nekog drugog kasnijeg Klaudijana. Za razliku od Gigantomahije, istraživači su primetili da njihova metrička tehnika nosi jasne tragove Nonovog uticaja, koji je pisao skoro pedeset godina posle Klaudijanove smrti. Postojanje tog drugog Klaudijana obično se zaključuje na osnovu odlomka iz Euagrijeve Crkvene

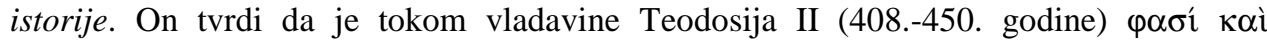

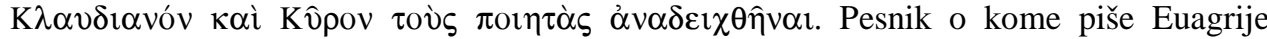
verovatno je kasniji Klaudijan, zaključuje Kameron, jer Kir je postao poznat tokom 430. godine, a bio je i konzul 441. godine. Pesme našeg Klaudijana se ne mogu datirati kasnije

\footnotetext{
${ }^{57}$ Peek, Gr. Versinscher. 1017 : tačka i zarez stavljene su proizvoljno; uporedi L. Robert, Hellenica II 1946, 105, f.n. 2

${ }^{58}$ Prevela Snežana Vukadinović.

${ }^{59}$ Carm.min. XXVIII.

${ }^{60}$ Carm.min. app. IX.

${ }^{61}$ Cameron 1970, 6.

${ }^{62}$ Carm.min. XII, 13-14.

${ }^{63}$ Prevela Snežana Vukadinović.
} 
od vladavine Teodosija II, jer je skoro sigurno da je do 408. godine, pesnik i umro ${ }^{64}$. Ako pođemo od činjenice da je Euagrije pisao skoro dva veka kasnije, možda je greškom stavio Klaudijana u vreme vladavine sledećeg cara, jer iz samog grčkog navoda vidi se da nije bio potpuno siguran što se tiče hronologije. Kako povezuje Klaudijana sa Kirom bez dodatnog obaveštenja nagoveštava da je pisao o čuvenom pesniku. Naš Klaudijan bez sumnje je bio najtalentovaniji i najistaknutiji pesnik svoje generacije i dvorski pesnik skoro čitavu deceniju. Harizmatično je delovao na svoje sledbenike, poput Sidonija Apolinara ${ }^{65}$, a najverovatnije je takav ili bar sličan uticaj imao i u grčkom svetu. Postoji još jedan dokaz, a to je lema za Antologiju Palatina ${ }^{66}$. Za Kamerona one su prilično nepouzdane. Sve što bi se sa sigurnošću moglo izvesti iz lema je pitanje da li je pisac tih kratkih izvoda znao Klaudijana koji je napisao delo Пó $\tau \rho \iota \alpha^{67}$.Izgleda da je pisac lema ovu informaciju dodao prvom pojavljivanju pesme pripisane Klaudijanu u_Antologiji. Istoimeni pesnici često se brkaju prilikom prepisivanja i u lemama Antologije ${ }^{6} 8$ i malo je verovatno da je pisac lema iz 10. veka imao bilo kakve valjane osnove za uočavanje razlike između autora Anth. Pal. (I, 19) i autora Gigantomahije ${ }^{69}$.

Istraživači nemaju jedinstven stav kada je reč o njegovoj porodici i društvenom položaju. Farg $^{70}$ je mišljenja da je bio skromnog porekla, jer nigde ne spominje svoju porodicu, dok Kameron realističnije gleda na stvari i sa sigurnošću zaključuje da je on potekao iz dobrostojeće porodice ${ }^{71}$. Zanimljivu hipotezu izneo je Teodor Birt ${ }^{72}$ na temelju jednog odlomka iz Eunapija ${ }^{73}$. Naime, Eunapije kaže da je sofist Maksim iz Efesa imao brata koji se zvao Klaudianus. Posle smrti cara Julijana 363. gtodine ${ }^{74}$ Klaudijan je otišao u Aleksandriju gde je otvorio retorsku školu. Birt se pita nije li on mogao biti otac našeg pesnika. Ova pretpostavka u prošlom veku nije našla nijedan dokaz da bi mogla biti tačna. Ali, ako protumačimo njegovo ime i prezime kako je to bio običaj davanja imena odnosno prezimena kod Grka, onda bi Birtova tvrdnja bila utemeljena. ${ }^{75}$ Bez obzira da li mu je otac bio retor i da li je imao retorsku školu, sa sigurnošću možemo zaključiti da je on potekao iz dobrostojeće porodice. Obrazovanje koje je morao steći, obično je bilo van domašaja svih, sem onih koji su bili bogati ${ }^{76}$. Oni koji su zaista želeli da dobiju najbolje moguće

\footnotetext{
${ }^{64}$ Ovo je hipoteza. Ne zna se kada je Klaudijan umro.

${ }^{65}$ Sidonije Apolinar (Gaius Sollius Modestus Apollinaris Sidonius), 5. vek, rodom iz Liona, latinski pisac. U svojim pesmama slavi političke veličine svoga doba, među njima svoga tasta, cara Avita. Njegova dela su značajna za kulturnu istoriju Galije.

${ }^{66}$ Anth. Pal. (I, 19).

${ }^{67}$ Pisanje Пó $\tau \rho \iota \alpha$ tj. legendi o nastanku gradova antičke Grčke i Male Azije, bilo je, izgleda, popularno u 4. i 5. veku. Vidi: A. Cameron, 1970, 8-11.

${ }^{68}$ A.S.F.Gow, The Greek Anthology: Sources and Ascriptions; Hell. Soc. Suppl. Paper IX, 1958.

${ }^{69}$ Cameron, 1970, 8.

${ }^{70}$ Fargues, 1933, 7.

${ }^{71}$ Cameron, 1970, 10.

${ }^{72}$ Birt 1892, V-VI.

${ }^{73}$ Vit. soph., 47, ed. Boisson.

${ }^{74}$ Amm. Marc. 25.3.

${ }^{75}$ Po sličnom principu građena su prezimena i kod nas, nastala od posesivnog prideva npr. Markov, Pavlov, dok se kod Graka koristio genitivus originis.

${ }^{76}$ Otac svetog Augustina je morao dugo da štedi dok nije skupio dovoljno sredstava da pošalje svog sina učitelju retorike u Madauruš (danas se tako zove taj grad u Alžiru ), a Augustin nikako ne bi mogao da završi studije u
} 
obrazovanje koje je novac mogao kupiti, studirali bi retoriku od četiri do devet godina. Bilo je uobičajeno provesti nekoliko godina u Antiohiji ili Aleksandriji, a zatim još nekoliko u Atini ili Konstantinopolju, kao i učiti od nekoliko različitih profesora. Oni čiji su roditelji bili pripremljeni i u mogućnosti da to plate, učili su kod najcenjenijih učitelja tog doba, gde god da su oni podučavali. ${ }^{77}$ Klaudijan je bez sumnje proveo nekoliko godina učeći u Aleksandriji. Pored izučavanja retorike i filozofije kao tradicionalnih predmeta kasnoantičkih škola, u Aleksandriji su se posebno negovale astronomija (uz nju i astrologija), matematika i medicina. Moguće je da upravo predavanjima u Aleksandriji Klaudijan duguje svoje živo interesovanje za te naučne discipline. U kasnom 4. veku u Aleksandriji je bilo mnogo talentovanih učitelja gramatike: Palada, Horapolon, Amonije, Heladije, koji su često i sami bili priznati pesnici i postojani pagani - koji su ga najverovatnije i ohrabrivali u proučavanju pesnika. Međutim, vrlo je moguće da je on takođe učio i u Atini, Antiohiji ili Konstantinopolju ${ }^{78}$. Kao što sam već napred rekla Egipćani su po Eunapiju ipak najviše cenili poeziju, tako da i talentovani Klaudijan nije učio samo da bi postao učen čovek, već se spremao za nešto više. Uostalom, njegova karijera se ne može pravilno razumeti, osim ako se ne shvati da je on bio pesnik po profesiji. Tako se dogodilo da je on jedini član napredne egipatske škole profesionalnih pesnika, čija su dela sačuvana. ${ }^{79}$ Ovi pesnici su sa pažnjom izučavali sve tehnike različitih pesničkih žanrova u kojima bi možda morali da pišu. Hvalospevi, pogrdne pesme, epitalamiji - svaki stil je imao svoja pravila i tajne. Klaudijanovi hvalospevi otkrivaju učeno poznavanje obrazaca i shema koje su postavili retoričari iz 3. i 4. veka, poput Menandera ${ }^{80}$ i Aftonija ${ }^{81}$.

Pesnici i filozofi koji su podučavali u Egiptu mahom su bili putujuće literate i pustolovi, pesnici od zanata koji su tražili određenu sumu novca za svoje usluge i, naravno, slavu. Ovi putujući pesnici, često su zapadali u razne neprilike jer su se, hteli oni to ili ne, upuštali u politiku i razne dvorske intrige. Obično su započinjali svoju karijeru pisanjem hvalospeva o nekom lokalnom zvaničniku. Generaciju pre Klaudijana, Andronik iz Hermopolisa je imao karijeru koja ga je vodila duž celog Istoka, a možda i do samog Rima, recitujući hvalospeve svom sugrađaninu, zvaničniku Foibamonu. Kir iz Antinopolja je započeo svoju karijeru veličajući lokalnog vojskovođu Morisa. ${ }^{82}$ Oni bi, kao što rekoh, bili plaćeni za svoju službu, bilo u novcu ili postavljanjem na neki položaj u civilnoj službi i dobijanjem imuniteta od plaćanja poreza i kurijskih dužnosti. Libanije savetuje svog prijatelja Heraklijana da mu pohvale peva pesnik Difil - ali ga upozorava da neće

Kartagini, posle smrti svog oca, da nije bilo pravovremene finansijske pomoći od strane porodičnog prijatelja. Vidi: Jones, LRE II, 1001; uporedi: Historia, XIV, 1965, 475, f.n.15; Cahiers d historie mondiale, X, 1967, 653 f.

${ }^{77}$ Sveti Vasilije, na primer, je nakon završetka svojih studija u Cezareji, otišao u Konstantinopolj, a zatim u Atinu. Uporedi A. Müler, Sstudentski život i putovanja u 4. veku ,Philologus, br. LXIX, 1910, 292 i dalje.

${ }^{78}$ Suda kaže da je u Teodosijevo vreme u Aleksandriji predavao veliki matematičar i filozof Teon, otac Hipatije. Vidi: Birt 1892: V. Role 1919, 137.; Marrou, 1963, 133-34, Cameron 1970, 22. O školovanju u Egiptu u kasnoj antici vidi: Demandt 1989, 352; Cameron, 1970, 22-23.

${ }^{79}$ Cameron 1965, 123-126, 165-166, 173-174.

${ }^{80}$ Cameron 1970, 32.

${ }^{81}$ Jelić 1997, 5-20.

${ }^{82}$ Vidi f. n. 43. 
biti $\alpha \mu \imath \sigma \theta^{\prime} .{ }^{83}$ A, „bedne stihove“ Dioskor iz Afroditopolja završava zahtevom za novcem. ${ }^{84}$ Može se zaključiti, da je ono što je bilo zajedničko svim ovim različitim prirodama i karakterima pesnika bilo to, da su bili vrlo obrazovani i svi su bili pagani u tada već hrišćanskom svetu.

Celi istočni deo rimskog carstva govorio je grčki, dok se latinski jezik slabo znao, a latinska proza i poezija gotovo se ignorisala. U kasnijem periodu Carstva, latinski je postao jezik imperije, ali samo na strogo praktičnom nivou, za one koji su želeli karijeru u profesijama koje su zahtevale makar osnovno znanje latinskog jezika, tačnije u pravu, vojsci, ili u administraciji. Kameron navodi Gibonova zapažanja i tvrdnje da ne postoji nijedna aluzija na Vergilija ili Horacija u kompletnoj grčkoj literaturi od Dionisija iz Halikarnasa do Libanija. Libanije je pokazao potpuni i razmetljivi prezir prema latinskom jeziku, koristeći prevodioca čak i da bi napisao pismo na latinskom, a car Julijan je uspeo da nauči toliko od latinskog da ga bar mogu razumeti Latine... disserendi sufficiens serm. Kako je Amijan ${ }^{85}$ zaštitnički primetio, a tako i Glover zaključuje u frazi „,izgleda da nije poznavao čak ni osnove književnosti pisane na latinskom jeziku,,. ${ }^{86}$ Suprotno ovom konvencionalnom stavu, što je bez sumnje bila posledica rastućeg interesovanja za latinski jezik, u Egiptu je posle Dioklecijanovih reformi, postojao jasan dokaz da je latinski jezik tamo proučavan u 4. i 5. veku. Papirusi su otkrili da su mnogi Egipćani u 4. veku počeli ne samo da stiču površno znanje zvaničnog latinskog jezika potrebno za trgovinu i svakodnevni život, već i da čitaju pristojan broj klasičnih autora, i to ne samo u tradicionalnim centrima učenja ${ }^{87}$. Uz to, učenici su počeli da ozbiljno proučavaju prozna dela poput Ciceronovog Katiline, kao i dela Salustija. U poeziji, kao što je i bilo za očekivati, dominirao je Vergilije. Postoji više papirusa o Vergiliju nego o bilo kom drugom latinskom piscu. ${ }^{88}$ Sredinom prošlog veka pronađeno je nekoliko tekstova Eneide sa stihovima koji su ispisani jedan do drugog (nijedan stariji od 4., ili mlađi od 6. veka), neki obeleženi akcentima i simbolima koji označavaju kvantitet. Takođe i pesnici ,srebrnog perioda,, bili su čitani, čak je u Antinopolju, u 5. veku izučavan i pesnik Juvenal uz podrobne komentare. ${ }^{89}$ Ako je to tačno za gradove Gornjeg Egipta, kaže Kameron, verovatno su postojali još bolji uslovi u Aleksandriji. U ranom 5. veku Prokle je došao iz Likije, a pred kraj tog veka Sever, budući patrijarh Antiohije, došao je iz Sozopolja u Aleksandriju da izučava latinske retorike. ${ }^{90}$

\footnotetext{
${ }^{83}$ Libanije, Ep., 969.

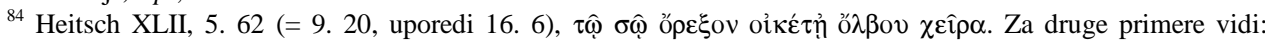
Historia XIV, 1965, 477-478.

${ }^{85}$ Am. Marc., XVI, 5, 7.

${ }^{86}$ Life and Letters in the Fourth Century, 1901, f.n.1

${ }^{87}$ Većina papirusa dolazi iz malih gradova kao što je Oksirinkus.

${ }^{88}$ Uporedi: P. Collart, Rev. de Phil. XV-3, 1941, 112 f.; R. Cavenaile, Corp. Pap. Lat., 1958, 7-117; G. Zalateo, Aegyptus 40, 1961, $196 \mathrm{f}$.

${ }^{89}$ Cameron, 1970, 20, f.n.2.

${ }^{90}$ Zacharias, Life of Severus, preveo Kugener, Dortmund 1957.; Patr. Orient., II, 1907, 498-512; Marinus, Life of Proclus,Oxford 1954.
} 
Latinski jezik Klaudijan je mogao naučiti u aleksandrijskim školama. Na osnovu dokaza koje pružaju papirusi možemo sa sigurnošću pretpostaviti da Klaudijan nije bio jedini koji je znao da piše pesme na latinskom jeziku.

Ne zna se tačno da li je Klaudijan napustio Aleksandriju pre 394. godine. Ako se to i desilo, kako neki istraživači tvrde, mesto njegovog odlaska bila je Atina ${ }^{91}$. Odlaskom na usavršavanje, pesnik je sigurno tom prilikom posetio slavne centre starih religija, sad već zatvorene ili srušene, ali i dalje poštovane kod mnogobrojnih poklonika. Ono što navodi mnoge istraživače na pomisao da je pesnik puno putovao je često spominjanje plovidbe morem, a to je potpuno u skladu sa navodima tadašnjih pesnika. Moguće je i da je boravio u Smirni ${ }^{92}$, a invektiva In Eutropium govori da je dobro poznavao Malu Aziju, a možda i Konstantinopolj ${ }^{93}$.

U svakom slučaju Klaudijan je verovatno krenuo na put nekoliko godina pre 394. godine, tačno u vreme kada su se u Aleksandriji događali krvavi neredi između hrišćana i pagana. Ako prihvatimo kao tačnu Augustinovu i Orozijevu tvrdnju da je Klaudijan bio paganin, onda je imao i te kako ozbiljan razlog da nestane iz Aleksandrije već 391. godine. Podsetimo se da su pagani 384. godine izgubili bitku oko oltara Pobede u senatu, te iste godine u Egipat je stigao novi pretorijanski prefekt Istoka Materno Cinegije (384.388. $)^{94}$. Jedan od njegovih glavnih zadatak bio je da zatvori sve paganske hramove, uništi idole i zapleni imovinu svetilišta u korist države i vojske. Taj plan se nije doslovno sprovodio, pa je hrišćane njegova nedoslednost sprovođenja naredbe još više razjarila, a naročito fanatičnu grupu monaha koji su zahtevali ne zatvaranje, već potpuno uništenje hramova i idola ${ }^{95}$. Posle krvavih obračuna u Tesaloniki 390. godine Teodosije zadaje konačni udarac paganima. Izdaje zakon 24. februara 391. godine i upućuje ga prefektu Rima Rufiju Albinu, u kojem se zabranjuje bilo kakav paganski kult i posećivanje hramova $^{96}$. U junu te iste godine iz Akvileje stiže Teodosijev ukaz o zabrani paganskih kultova u Egiptu ${ }^{97}$, a sledeće 392. godine zabranjen je i privatni paganski kult, kao paljenje vatre Larima, libacije Genijima, paljenje mirisnih trava Penatima, ukrašavanje idola vencima i dr. ${ }^{98}$ Ovo su bili povodi da se svuda u Egiptu, a naročito u Aleksandriji rasplamsaju žestoki sukobi između pagana i hrišćana. Fanatični aleksandrijski arhiepiskop Teofil odlučio je da se uništi najveći i najslavniji od svih hramova Serapeion. Rušenje Serapisovog hrama praćeno je svirepim i krvavim neredima između Teofilovih

\footnotetext{
${ }^{91}$ Atina je bila tada središte paganskog učenja, kako filozofskog, tako i teološkog. Ljudi koji su želeli bilo kakvu karijeru među učenim paganima morali su bar neko vreme provesti u Atini. Vidi: Athanassiadi, 1993, 5-9.

${ }_{92}$ Ako prihvatimo Birtovu hipotezu da je Klaudijan zaista sin Klaudijana, brata Maksima iz Efesa, koji se odselio u Aleksandriju, onda je naš pesnik imao strica u Smirni, Nimfidijana koji je bio drugi Maksimov brat i u isto vreme je napustio Efes i otišao za Smirnu. Naravno ovo su sve pretpostavke ali nisu podkrepljene pravim dokazima. Vidi: Birt 1892, V-VI.

${ }^{93}$ Cameron 1970, 26-27.

${ }^{94}$ Libanije, Or. 30., 3., 48

${ }^{95}$ C.Th. 16.10.9, Liban., Pro Templis 10; Zosim, 50.4.

${ }^{96}$ Zabranjuje se ulaženje u hramove i ukazivanje pošte božanstvu, zabranjuje se prinošenje žrtava (immolatio), proricanje iz utrobe žrtvovane životinje proglašeni su izdajom države i kažnjeni su smrću, dok se posećivanje hramova kažnjavalo globom u zlatu.

${ }^{97}$ C.Th. 16. 10.10; 16.7.4-5; 16.10 .11 .

${ }^{98}$ Bury 1923, 368-69; K. Latte, Römisches Religionsgeschichte, München 1960, 370-73.
} 
hrišćanskih fanatika i ekstremnih pagana koje je predvodio filozof Olimpije. Posle rušenja Serapisovog hrama većina paganskih branitelja ${ }^{99}$ napustila je Aleksandriju.

A gde je bio Klaudijan u to vreme? Mladi pesnik, po svemu sudeći, nije učestvovao u ovim krvavim neredima. $U$ to vreme Klaudijan je mogao imati nepunih dvadesetak godina, a uz to i žarku želju da se ostvari kao pesnik i zaobiđe agresivnu politiku novoveračke religije na čelu sa aleksandrijskim arhiepiskopom Teofilom. Kameron i Švarc tvrde da je Klaudijan otišao iz Aleksandrije 391 . godine ${ }^{100}$, što je najverovatnije i tačno. Šta se dogodilo sa njim u tim godinama ništa se pouzdano ne zna, ali većina istraživača misli da se tokom 394. godine Klaudijan obreo u Rimu. Da li je došao pravo iz Aleksandrije u Rim bila je, takođe, tema nekih istraživača ${ }^{101}$. Ako znamo da je većina putujućih pesnika ${ }^{102}$ Grka odlazila u Atinu, Konstantinopolj ili Antiohiju, zašto je Klaudijan izabrao, baš, Rim kao mesto gde bi mogao ostvariti svoje ambicije, to je i danas otvoreno pitanje za mnoge istraživače. Možda se mladi pesnik nadao da je život pagana jednostavniji pre u Italiji nego na Istoku, a možda sudbina jednog drugog Aleksandrijca tog vremena može da nam objasni razloge njegovog dolaska u Rim. Eunapije $^{103}$ spominje nekog Euzebija iz Aleksandrije koji je odlučio da ode u Rim, jer je znao, kako je sam rekao, veštinu ulagivanja moćnicima. ${ }^{104}$ Izgleda da je ta veština Klaudijanu išla od ruke te se bez dvoumljenja uputio u Rim.

Rim je, bez obzira što je izgubio čast prestonice, i dalje držao do slave i veličine. Paganska kultura i dalje je prožimala sve pore rimskog društva, i dalje se živelo, bar kad je aristokratska klasa u pitanju, po paganskim običajima. Iako je veliki deo grada propadao, središnji deo Rima, Forum i Kapitol zadržali su svoj stari sjaj. Rim je nastavio da bude svetla tačka paganskih hramova. Tačno je da su 395. godine hramovi bili zatvoreni, ali neki su bili obnavljani, kao što je rekonstruisan Saturnov hram ili sagrađeni kao Porticus deorum consentium ${ }^{105}$. Dolaskom u Rim, Klaudijan je, sigurno, bio očaran

\footnotetext{
${ }^{99}$ Olimpije je otišao u Italiju, Amonije i Heladije sklonili su se u Konstantinopolj i bavili se podučavanjem. Vidi: Athanassiadi 1993, 15. 
lepotom Rimskih građevina koje su svojom impozantnošću na svakom koraku veličale slavu i prošlost Rima. Ta prva mladalačka impresija ostala je prisutna u čitavom pesnikovom stvaralaštvu, ona ga je podstakla i zadužila da svoj talenat ostavi baš ovde, na italskom tlu. Takvo iskustvo nisu delili svi došljaci sa grčkog istoka. Amijan Marcelin ${ }^{106}$ govori da su se stranci teško uklapali. Naš pesnik se izgleda još u rodnom gradu pobrinuo da dobije preporuku nekog uglednog čoveka iz Aleksandrije ili možda Atine, koja bi mu pomogla da uđe u prave krugove moćnih ljudi tadašnjeg vremena. Ubrzo je Klaudijan postao klijent bogatih i uglednih ljudi ${ }^{107}$ i time započeo svoju blistavu karijeru u Rimu.

${ }^{106}$ Am. Marc. 14.6; 28.4.

${ }^{107}$ Primera za takav život je mnogo. Vidi: Boissier II 1894, 240. 
Izvori i literatura:

Alföldi, A., A Conglict of Ideas in the Late Romane Empire, Oxford 1952.

Athanassiadi, P., Persecution and response in late paganus: the evidence of Damascius, Journal of Hellenic Studies, br. 113, 1993.

Bertelli, C., Roma e Milano all' ultimo conflitto col paganesimo, aspetti della committenza cristiana, Milani 1992.

Birt, T., Claudii Claudiani Carmina recensuit Th Birt, Berolini 1892 (Monumenta Germaniae Historica, Auctorum Antiquissimorum tomus X)

Boissier, G., La fin du paganisme. Etude sur les dérnièrs luttes religieusses en Occident au quatrième siècle, 2. izdanje, Paris 1894.

Bloch, H., The Pagan Revival in the West at the End of the Fouth Century, Oxford 1963.

Bowersock, G.W., Hellenism in Late Antiquity, Cambridge 1990.

Bury, J. B., Hystory of the Later Roman Empire, I, London 1923.

Cameron, A., Wandering Poets: A Literary Movement in Byzantine Egipt, Historia XIV, str. 470509.

Cameron, A., CLAUDIAN, Poetry and Propaganda at the Court og Honorius, Oxford 1970.

Clarke, A.K., Claudian and the Augustinian circle of Milan, Augustinus, 1968, 45-54.

Fargues, P., CLAUDIEN Etude sur sa poésie et son temps, Paris 1933.

Hall. J.B., CLAUDIAN. De raptu Proserpinae. Edited with an Introduction and Commentary, Cambridge 1969

Jelić, V., ПРОГYMNA ГMATA retora Aftonija-pripremne vežbe za besednike, prevod, predgovor i napomene Vojislav Jelić, MS i SANU, Novi Sad - Beograd 1997.

Latte, K., Römisches Religionsgeschichte, München 1960.

Leppin, H., Teodosius der Grosse Wissenschafliche Buchgesellschaft, Darmstand 2003.

MacMullen, R., Paganism In the Roman Empire, Yale Univ. Press, New Haven 1981.

Milićević, M., Klaudije Klaudijan - Otmica Prozerpine, Zagreb 1997.

Nolan, J. F., Claudian: Poet of Peace and Unity in the Later Empire, diss. Un. of Washington 1973. (University Micro-films, A Xerox Company, Ann Arbor, Michigen)

Otto, W. F., Theophania Duh starogrčke religije, preveo i priredio Damir Barbarić, MH, Zagreb 1998.

Pietri, Ch., Aristocratie milanaise paiens et chretien au IVe siècle, Milano, 1992.

Platnauer, M., Claudian, trans. M.Platnauer, Loeb Classical Library, Univ. Press Harvard 1922.

Salopek, D., Sironić, M., Vratović V., Hosu. S., Povijest svjetske književnosti, knj.2, Zagreb 1977.

Wifstrand, A., Von Kallimachos zu Nonnos, Lund 1933. 


\title{
SNEŽANA VUKADINOVIĆ
}

\section{„ALEXANDRIA FED ME, ROMA WHELMED ME AS A REFUGEE“}

\begin{abstract}
Summary
The background of Claudian`s life was rich of Egyptian literary color, which was the Roman province during the fourth and the fifth century. A number of relevant historical sources indirectly referred to the life and education of Claudius Claudianus. His mother-tongue was Greek, but during his education in Alexandria Claudian also taught Latin.

The paper listed the names of the great poets of the late Roman Empire, who crucially influenced Claudianus poetic style. The Greek and Roman literature in Egypt, and its cultural and educational centers, were not equally important and cultivated. Only after the Diocletian`s reforms of Roman literature, Latin was studied in details in Alexandria, Hermopolis, Aphroditopolis, Thebes and other centers. From that period, Roman poets and writers started to study Latin, especially the "silver Latin". This fact was confirmed by the latest archaeological findings of the papyrus, during the sixties of the twentieth century.
\end{abstract}

Keywords: Claudianus Claudius, Claudius Claudian, Egypt, Egyptian poets, Alexandria, Rome. 